\title{
MEDIA505IAN
}

Jurnal IImu Sosial dan IImu Administrasi Negara Vol.05 No.02 Tahun 2021

\section{PERBANDINGAN REFORMASI MANAJEMEN PUBLIK INDONESIA DAN PERANCIS}

\author{
*Nanang Haryono ${ }^{1)}$ \\ ${ }^{1)}$ Fakultas Ilmu Sosial dan Ilmu Politik Universitas Airlangga \\ *Email Korespondensi: nanang.haryono@ fisip.unair.ac.id
}

\begin{abstract}
Abstrak
Kajian perbandingan administrasi publik telah berkembang sejalan dengan perkembangan ilmu administrasi publik. Tujuan paper ini adalah mengetahui reformasi manajemen publik di Indonesia dikomparasikan dengan Prancis. Komparasi ini tidak mendudukkan Indonesia vis a vis dengan Prancis, namun untuk menemukan lesson learned untuk membangun Indonesia menjadi lebih baik. Metode yang digunakan adalah studi pustaka. reformasi manajemen publik di Indonesia mempertahankan banyak fitur inti dari negara neopatrimonial yang fundamental, di mana elit politik dan ekonomi yang berkuasa melakukan kontrol ketika beroperasi dalam administrasi publik Weberian. Model reformasi negara Prancis sebagaimana negara-negara eropa kontinental berdasarkan modernisasi (Bouckaert, Pollitt, 2000). Pada negara Prancis, menganggap administrasi negara sebagai domain otonom terpisah dari masyarakat sipil '(Clark, 1998, hal. 100) dan diatur oleh aturan hukum. Berdasarkan studi komparasi reformasi manajemen publik di Indonesia dan Prancis lesson learned yang dapat penulis sampaikan adalah: a) Pelaksanaan Reformasi pada suatu negara harus memperhatikan aspek proses sosial-ekonomi, sistem politik, kebijakan elit berkuasa, dan sistem administrasi; b) Reformasi pada negara maju maupun negara berkembang cenderung mengarah pada penciptaan good government dengan mengadopsi prinsipprinsip NPM pada tata pemerintahan; c) Dorongan reformasi untuk membangun good government dengan menerapkan NPM melalui paket-paket reformasi harus dibaca ulang disesuaikan dengan karakteristik sosial, budaya, politik dan kondisi masyarakat suatu negara.
\end{abstract}

\section{Kata kunci: perbandingan reformasi, manajemen publik.}

\begin{abstract}
Comparative studies of public administration have developed in line with the development of public administration science. The purpose of this paper is to find out public management reform in Indonesia compared to France. This comparison does not place Indonesia vis a vis with France, but to find lessons learned to build a better Indonesia. The method used is literature study. Indonesia's public management reforms retain many of the core features of a fundamentally neopatrimonial state, over which the ruling political and economic elite exercise control while operating within the Weberian public administration. The French state reform model as continental
\end{abstract}




\section{MEDIA505IAN}

Jurnal IImu Sosial dan IImu Administrasi Negara Vol.05 No.02 Tahun 2021

European countries is based on modernization (Bouckaert, Pollitt, 2000). The French state considers state administration as an autonomous domain separate from civil society' (Clark, 1998, p. 100) and governed by the rule of law. Based on a comparative study of public management reform in Indonesia and France, the lessons learned that the author can convey are: a) The implementation of reform in a country must pay attention to aspects of socio-economic processes, political systems, policies of the ruling elite, and administrative systems; b) Reforms in both developed and developing countries tend to lead to the creation of good government by adopting the principles of NPM in governance; c) The impetus for reform to build good government by implementing NPM through reform packages must be re-read in accordance with the social, cultural, political and social characteristics of a country.

\section{Keywords: comparative reform, public management}

\section{PENDAHULUAN}

Kajian perbandingan administrasi publik telah berkembang sejalan dengan perkembangan ilmu administrasi publik. Kajian perbandingan administrasi publik dibutuhkan untuk kebutuhan praktis yang dinamis dan tren global yang memerlukan pengembangan. Merujuk pendapat (Riggs, 1991) pengalaman Amerika yang benar-benar luar biasa pada pengembangan Ilmu Administrasi, mengarahkan pengembangan studi perbandingan administrasi publik pada studi pemerintahan "negara lain" sebagai objek kajian. Riggs menyimpulkan, bahwa proses studi perbandingan administrasi menghasilkan pengetahuan administrasi yang andal dan mengembangkan prinsipprinsip administrasi terpercaya secara inheren.

Berdasarkan pada pijakan pendapat Riggs tersebut pada kuliah Sejarah dan Teori Perbandingan Administrasi Publik penulis akan membahas perbandingan Indonesia dan Prancis dari aspek reformasi manajemen publik. Perbandingan administrasi publik yang lintas budaya bermanfaat untuk membuat penilaian yang lebih baik bagi cendikiawan ilmu administrasi tentang konteks global. Informasi tersebut meningkatkan analisis dan meningkatkan pengetahuan dan penilaian tentang administrasi publik. Pada kajian perbandingan administrasi publik, (Riggs, 1991) mencatat tentang konteks Administrasi Publik.

Menariknya kajian perbandingan administrasi publik adalah:

a) Pertama, perbandingan administrasi publik pencarian pola dan keteraturan tindakan dan perilaku melalui analisis komparatif di antara negara-negara. 


\section{MEDIA505IAN}

Jurnal IImu Sosial dan IImu Administrasi Negara Vol.05 No.02 Tahun 2021

b) Kedua, metode komparatif sangat penting untuk pengembangan teori administrasi dan meningkatkan penerapannya (Heady, 2001).

c) Ketiga, studi komparatif lembaga mempromosikan pemahaman tentang karakteristik global, yang disebabkan oleh revolusi teknologi informasi. Karena perspektif komparatif memiliki efek pada administrasi publik untuk melihat tindakan yang lebih luas, mengidentifikasi berbagai masalah dan secara bersamaan, meningkatkan pemahaman kita tentang kekurangan dan keterbatasan konteks administrasi kita sendiri.

d) Keempat, administrasi publik komparatif menekankan reformasi dan pengembangan, dan penelitian komparatif berpusat pada karakteristik dan kondisi sistem administrasi yang terkait dengan kinerja yang baik. (Lynn Jr, 1998) menekankan, warisan konstruktif untuk bidang pelayanan publik dan reformasi administrasi

e) Kelima, pengetahuan dan informasi yang dihasilkan melalui metode komparatif, melayani kebutuhan praktisi dan memperluas cakrawala. Melalui perbandingan, praktisi meningkatkan kapasitas mereka untuk mengamati, belajar, dan meningkatkan kinerja manajerial (Jreisat, 2005).

Ketika membandingkan pengalaman lintas batas negara, para manajer yang berlatih mendapatkan pemahaman yang lebih dalam tentang institusi mereka, perubahan demografi komunitas mereka, dan "konteks politik yang berbeda" yang mereka hadapi (Khademian, 1998).

Tujuan paper ini adalah mengetahui reformasi manajemen publik di Indonesia dikomparasikan dengan Prancis. Komparasi ini tidak mendudukkan Indonesia vis a vis dengan Prancis, namun untuk menemukan lesson learned untuk membangun Indonesia menjadi lebih baik. Sebelum membahas lebih jauh, berikut akan dipaparkan aspek geografis, sistem pemerintahan, ekonomi, kepartaian kedua negara. Pembahasan reformasi menajemen publik perlu melihat lebih dulu aspek-aspek tersebut. Hal ini karena kebijakan reformasi manajemen publik dipengaruhi aspek internal maupun eksternal yang ada dalam negara tersebut.

\section{Geografis Indonesia dan Prancis}

Secara geografis negara Indonesia terletak di Asia Tenggara dan negara Prancis terletak di benua eropa. Perbedaan kondisi geografis ini dikaitkan dengan negara-negara disekitarnya yang 


\section{MEDIA505IAN}

Jurnal IImu Sosial dan IImu Administrasi Negara Vol.05 No.02 Tahun 2021

mempengaruhi budaya, keilmuan, perkembangan ekonomi, dan tata pemerintahan. Berikut ditunjukkan letak geografis negara Indonesia dan Prancis.

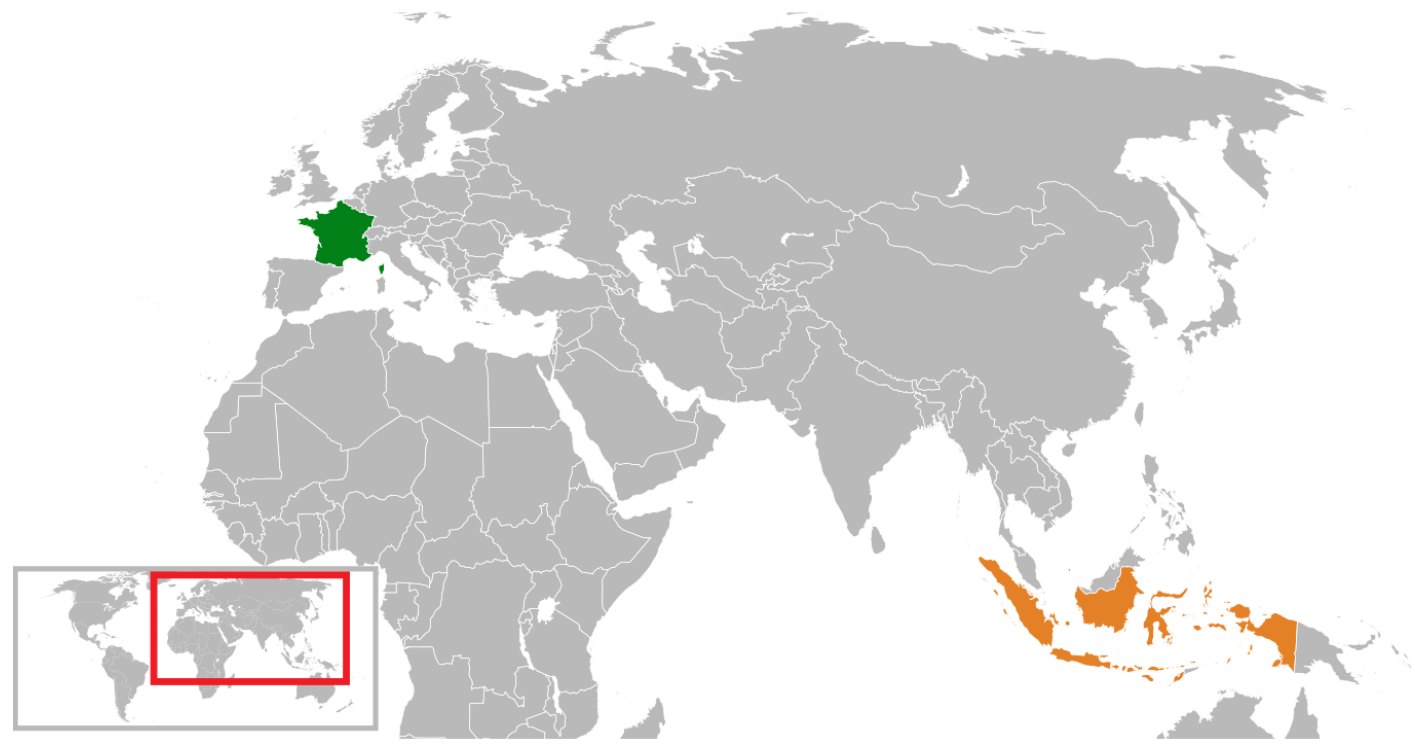

Gambar 1 Letak Geografis Negara Indonesia dan Negara Prancis

Sumber: https://en.wikipedia.org/wiki/File:France_Indonesia_Locator.svg. Akses 2 Juni 2020.

\section{PERBANDINGAN SISTEM PEMERINTAHAN INDONESIA DAN PRANCIS PRANCIS}

Prancis secara resmi Republik Perancis (Prancis: République française) adalah negara yang wilayahnya terdiri dari metropolitan Prancis di Eropa Barat dan beberapa wilayah dan wilayah luar negeri. Wilayah metropolitan Prancis membentang dari Laut Mediterania hingga Selat Inggris dan Laut Utara, dan dari Rhine ke Samudra Atlantik. Berbatasan dengan Belgia, Luksemburg, dan Jerman di timur laut, Swiss, Monako, dan Italia di timur, serta Andorra dan Spanyol di selatan. Wilayah luar negeri termasuk Guyana Prancis di Amerika Selatan dan beberapa pulau di Atlantik, Pasifik, dan samudera Hindia. 18 wilayah integral negara itu (lima di antaranya berada di luar negeri) menjangkau wilayah gabungan 643.801 kilometer persegi (248.573 mil persegi) dan total populasi 67,07 juta (per Mei 2020).

Prancis menerapkan sistem semi-presidensial kesatuan dengan ibukotanya di Paris. Kota Paris merupakan yang terbesar di negara Prancis dan pusat budaya dan komersial utama. Daerah 


\section{MEDIA505IAN}

Jurnal IImu Sosial dan IImu Administrasi Negara Vol.05 No.02 Tahun 2021

perkotaan utama lainnya termasuk Lyon, Marseille, Toulouse, Bordeaux, Lille dan Nice. Prancis, termasuk wilayahnya di luar negeri, memiliki zona waktu paling banyak di negara mana pun, dengan total 12 zona waktu.

Republik Perancis adalah memiliki tradisi demokrasi yang kuat. Konstitusi Republik Kelima disetujui melalui referendum pada tanggal 28 September 1958. Konstitusi tersebut memperkuat otoritas eksekutif dalam kaitannya dengan parlemen. Cabang eksekutif itu sendiri memiliki dua pemimpin: Presiden Republik, saat ini Emmanuel Macron, yang adalah kepala negara dan dipilih langsung oleh hak pilih orang dewasa universal untuk masa jabatan 5 tahun (sebelumnya 7 tahun), dan Pemerintah, dipimpin oleh Perdana Menteri yang ditunjuk oleh presiden.

Parlemen Prancis adalah badan yang terdiri dari Majelis Nasional (Assemblée nationale) dan Senat (gambar 4) . Deputi Majelis Nasional mewakili konstituensi lokal dan secara langsung dipilih untuk masa jabatan 5 tahun. Majelis memiliki kekuatan untuk memberhentikan pemerintah, dan dengan demikian mayoritas dalam Majelis menentukan pilihan pemerintah. Senator dipilih oleh rakyat untuk masa jabatan 6 tahun (semula masa jabatan 9 tahun), dan setengah dari kursi diajukan ke pemilihan setiap 3 tahun. Kekuatan Senat terbatas; dalam hal terjadi perselisihan antara kedua kamar, Majelis Nasional memiliki keputusan akhir. Pemerintah memiliki pengaruh kuat dalam membentuk agenda Parlemen.

\section{INDONESIA}

Indonesia secara resmi Republik Indonesia adalah negara di Asia Tenggara. Indonesia terdiri dari lebih dari tujuh belas ribu pulau, termasuk Sumatra, Jawa, Kalimantan, Sulawesi, dan Papua. Indonesia adalah negara kepulauan terbesar di dunia dan negara ke 14 terbesar berdasarkan luas daratan, pada 1.904 .569 kilometer persegi (735.358 mil persegi). Dengan lebih dari 267 juta jiwa. Indonesia adalah negara dengan populasi terpadat ke-4 di dunia dan juga negara dengan populasi Muslim terbesar. Indonesia terbagi atas 34 provinsi, yang lima memiliki status khusus. Ibukota negara ini, Jakarta, adalah wilayah perkotaan terpadat kedua di dunia. Negara ini berbagi perbatasan darat dengan Papua Nugini, Timor Timur, dan bagian timur Malaysia. Negara tetangga 


\section{MEDIA505IAN}

Jurnal IImu Sosial dan IImu Administrasi Negara Vol.05 No.02 Tahun 2021

lainnya termasuk Singapura, Vietnam, Filipina, Australia, Palau, dan Kepulauan Andaman dan Nicobar di India.

Indonesia menerapkan sistem presidensial. Pasca reformasi pada tahun 1998, struktur politik dan pemerintahan telah mengalami perubahan besar. Melalui empat amandemen konstitusi mengubah kewenangan eksekutif, legislatif dan yudikatif (gambar 2). Presiden Indonesia adalah kepala negara dan kepala pemerintahan, panglima tertinggi Tentara Nasional Indonesia (TNI), dan direktur pemerintahan dalam negeri, pembuatan kebijakan, dan urusan luar negeri. Presiden dapat dipilih maksimal dua masa jabatan lima tahun berturut-turut. Badan perwakilan tertinggi di tingkat nasional adalah Majelis Permusyawaratan Rakyat (MPR). MPR terdiri dari dua kamar yaitu Dewan Perwakilan Rakyat (DPR), dengan 575 anggota, dan Dewan Perwakilan Daerah (DPD), dengan 136. Sejak tahun 1999 Indonesia menerapkan sistem multi-partai.

Tabel 1

Perbandingan Indonesia dan Prancis dari Aspek Pemerintahan, Legislatif

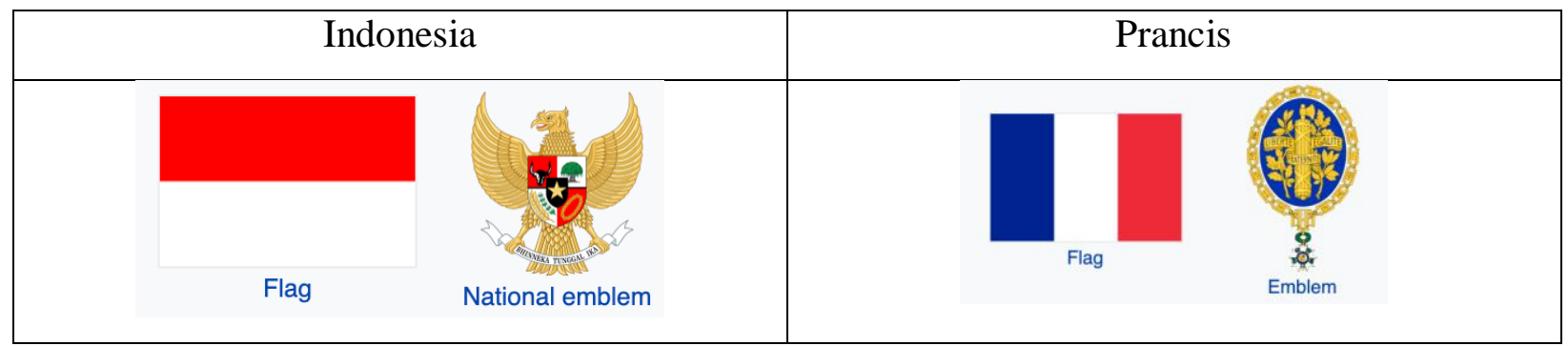




\section{MEDIA505IAN}

Jurnal IImu Sosial dan IImu Administrasi Negara Vol.05 No.02 Tahun 2021

\begin{tabular}{|c|c|c|c|}
\hline $\begin{array}{l}\text { Capital } \\
\text { and largest city }\end{array}$ & $\begin{array}{l}\text { Jakarta } \\
6^{\circ} 10^{\prime} \mathrm{S} 106^{\circ} 49^{\prime} \mathrm{E}\end{array}$ & $\begin{array}{l}\text { Capital } \\
\text { and largest city }\end{array}$ & $\begin{array}{l}\text { Paris } \\
\nabla^{\circ} 51^{\prime} \mathrm{N} 22^{\circ} 21^{\prime} \mathrm{E}\end{array}$ \\
\hline \multirow{2}{*}{$\begin{array}{l}\text { Official language } \\
\text { and national } \\
\text { language } \\
\text { Regional } \\
\text { languages }\end{array}$} & Indonesian & $\begin{array}{l}\text { Official language } \\
\text { and national language }\end{array}$ & French $^{[l]}$ \\
\hline & Over 700 languages $^{[3]}$ & Nationality (2018) & $\begin{array}{l}93.0 \% \text { French citizens } \\
7.0 \% \text { foreign } \\
\text { nationals }^{[1]}\end{array}$ \\
\hline Ethnic groups & $\begin{array}{l}\text { Over } 300 \text { ethnic } \\
\text { groups }^{[4]}\end{array}$ & \multirow[t]{2}{*}{ Religion $\left(2017^{[2]}\right)$} & \multirow{2}{*}{$\begin{array}{l}57.5 \% \text { Roman Catholic } \\
35 \% \text { Non-religious } \\
3.5 \% \text { other faiths } \\
3 \% \text { Protestant } \\
1 \% \text { Unanswered }\end{array}$} \\
\hline \multirow[t]{3}{*}{ Religion (2018) ${ }^{[5]}$} & \multirow{3}{*}{$\begin{array}{l}\text { 86.7\% Islam } \\
\text { 10.72\% Christianity } \\
1.74 \% \text { Hinduism } \\
0.77 \% \text { Buddhism } \\
\text { 0.03\% Confucianism } \\
0.04 \% \text { Folk }\end{array}$} & & \\
\hline & & Demonym(s) & French \\
\hline & & Government & $\begin{array}{l}\text { Unitary semi- } \\
\text { presidential } \\
\text { constitutional republic }\end{array}$ \\
\hline Demonym(s) & Indonesian & \multirow{3}{*}{$\begin{array}{l}\text { - President } \\
\text { - Prime Minister } \\
\text { - President of the } \\
\text { Senate } \\
\text { - President of the } \\
\text { National Assembly }\end{array}$} & \multirow{2}{*}{$\begin{array}{l}\text { Emmanuel Macron } \\
\text { Édouard Philippe } \\
\text { Gérard Larcher }\end{array}$} \\
\hline Government & $\begin{array}{l}\text { Unitary presidential } \\
\text { constitutional republic }\end{array}$ & & \\
\hline \multirow{2}{*}{$\begin{array}{l}\text { - President } \\
\text { - Vice President } \\
\text { - DPR Speaker } \\
\text { - Chief Justice }\end{array}$} & \multirow{2}{*}{$\begin{array}{l}\text { Joko Widodo } \\
\text { Ma'ruf Amin } \\
\text { Puan Maharani } \\
\text { Muhammad Syarifuddin }\end{array}$} & & Richard Ferrand \\
\hline & & \multirow{2}{*}{$\begin{array}{l}\text { Legislature } \\
\text { - Upper house } \\
\text { • Lower house }\end{array}$} & \multirow{2}{*}{$\begin{array}{l}\text { Parliament } \\
\text { Senate } \\
\text { National Assembly }\end{array}$} \\
\hline Legislature & $\begin{array}{l}\text { People's Consultative } \\
\text { Assembly (MPR) }\end{array}$ & & \\
\hline $\begin{array}{l}\text { - Upper house } \\
\text { - Lower house }\end{array}$ & $\begin{array}{l}\text { Regional Representative } \\
\text { Council (DPD) } \\
\text { People's Representative } \\
\text { Council (DPR) }\end{array}$ & \multirow{2}{*}{$\begin{array}{l}\text { Area } \\
\text { - Total } \\
\text { - Metropolitan France } \\
\text { (IGN) }\end{array}$} & $\begin{array}{l}640,679 \mathrm{~km}^{2} \\
(247,368 \mathrm{sq} \mathrm{mi})^{[3]} \\
(42 \mathrm{nd})\end{array}$ \\
\hline \multirow{2}{*}{$\begin{array}{l}\text { Area } \\
\cdot \text { Land }\end{array}$} & & & $\begin{array}{l}551,695 \mathrm{~km}^{2} \\
(213,011 \mathrm{sq} \mathrm{mi})^{[\mathrm{V}]} \\
(50 \mathrm{th})\end{array}$ \\
\hline & $\begin{array}{l}1,904,569^{[6]} \mathrm{km}^{2} \\
(735,358 \mathrm{sq} \mathrm{mi})(14 \mathrm{th}) \\
4.85\end{array}$ & $\begin{array}{l}\text { - Metropolitan France } \\
\text { (Cadastre) }\end{array}$ & $\begin{array}{l}543,940.9 \mathrm{~km}^{2} \\
(210,016.8 \mathrm{sq} \mathrm{mi})^{[\mathrm{VI}][4]} \\
(50 \mathrm{th})\end{array}$ \\
\hline \multirow{3}{*}{$\begin{array}{l}\text { Population } \\
\text { - } 2018 \text { estimate } \\
\text { - } 2010 \text { census } \\
\text { - Density }\end{array}$} & $\begin{array}{l}267,670,543^{[7][8]} \\
237,641,326^{[9]}(4 \text { th })\end{array}$ & $\begin{array}{l}\text { Population } \\
\text { - May } 2020 \text { estimate } \\
\text { - Density }\end{array}$ & $\begin{array}{l}\nabla 67,067,000^{[5]}(20 \mathrm{th}) \\
104 / \mathrm{km}^{2}(270 / \mathrm{sq} \mathrm{mi}) \\
(106 \mathrm{th})\end{array}$ \\
\hline & $\begin{array}{l}138 / \mathrm{km}^{2} \text { (357.4/sq mi) } \\
\text { (88th) }\end{array}$ & \multirow{2}{*}{$\begin{array}{l}\text { - Metropolitan France, } \\
\text { estimate as of May } \\
2020 \\
\text { - Density }\end{array}$} & $\nabla 64,898,000^{[6]}(22 n d)$ \\
\hline & & & $\begin{array}{l}\text { 116/km² (300.4/sq mi) } \\
\text { (89th) }\end{array}$ \\
\hline
\end{tabular}

Sumber data: 


\section{MEDIA505IAN}

Jurnal IImu Sosial dan IImu Administrasi Negara Vol.05 No.02 Tahun 2021

Prancis. https://en.wikipedia.org/wiki/France\#Government;

Indonesia.https://en.wikipedia.org/wiki/Indonesia\#Government_and_politics. Akses 2 Juni 2020.

\section{SISTEM TATA PEMERINTAHAN INDONESIA DAN PRANCIS}

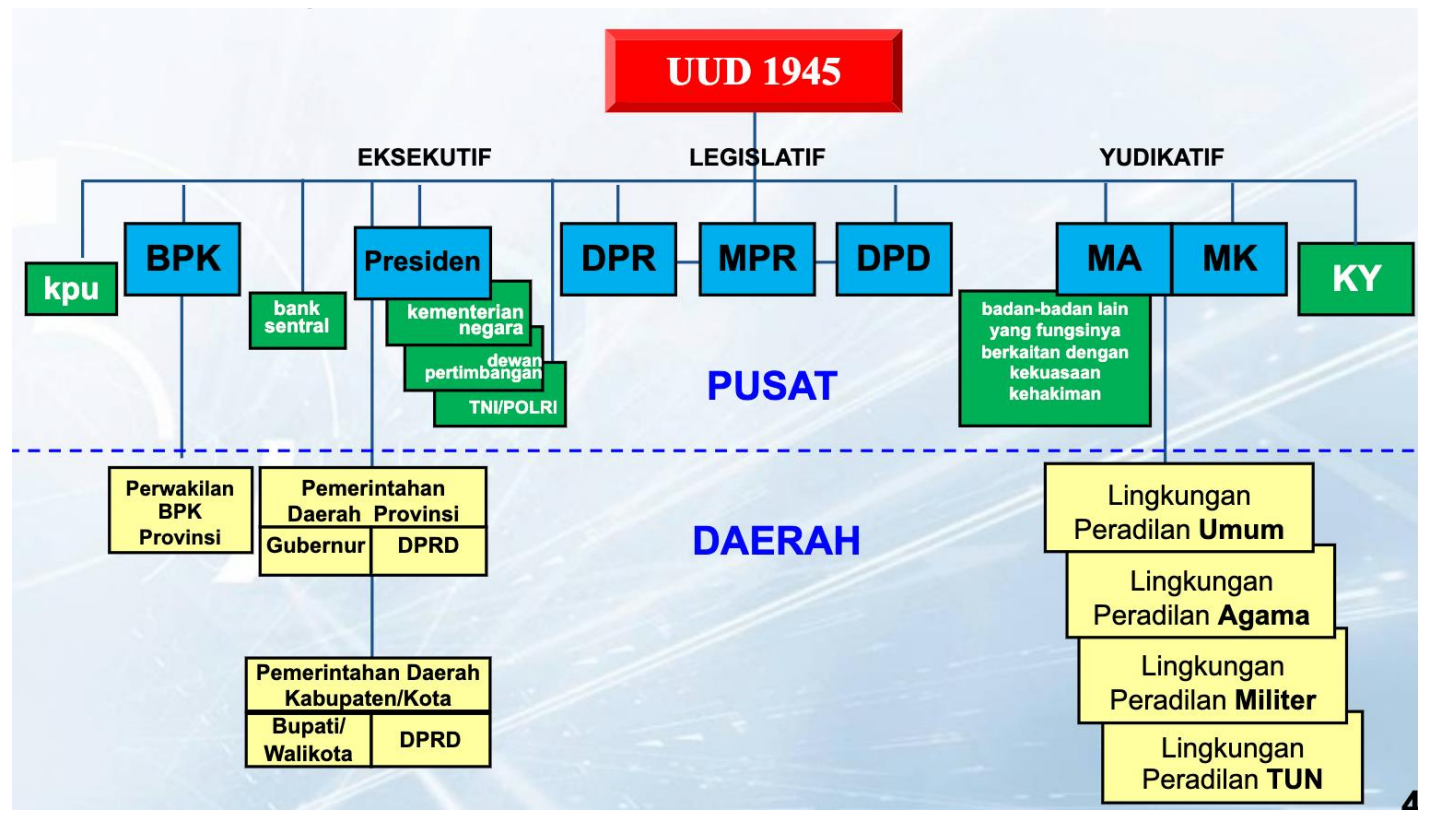

Gambar 2 Tata Pemerintahan Indonesia

Sumber data: paparan mendagri, 2014. 


\section{MEDIA505IAN}

Jurnal IImu Sosial dan IImu Administrasi Negara Vol.05 No.02 Tahun 2021

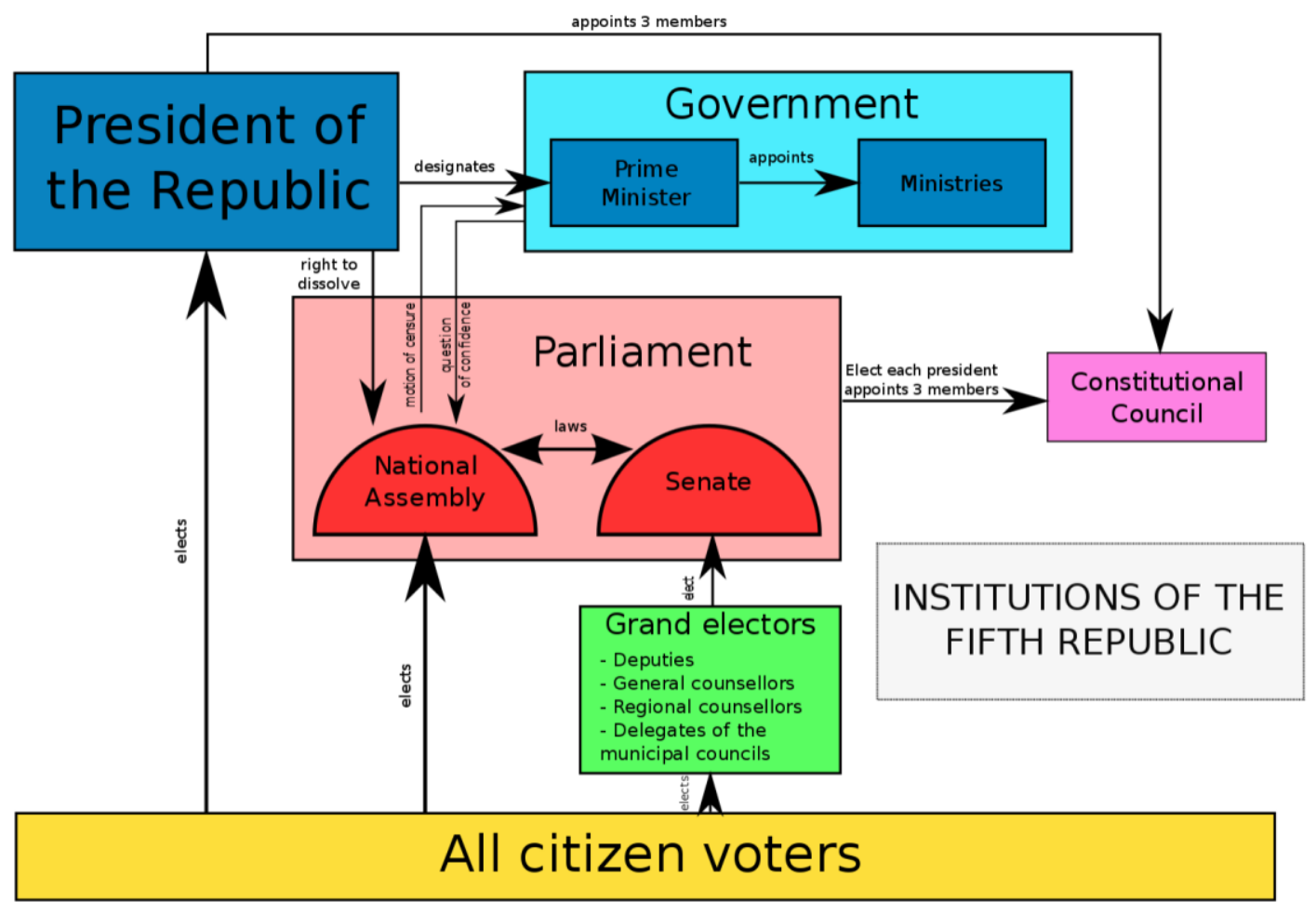

Gambar 3 Institutions of the Fifth Republic

Sumber: Institutions of the Fifth Republic. https://en.wikipedia.org/wiki/French Fifth Republic 


\section{MEDIA505IAN}

Jurnal IImu Sosial dan IImu Administrasi Negara Vol.05 No.02 Tahun 2021

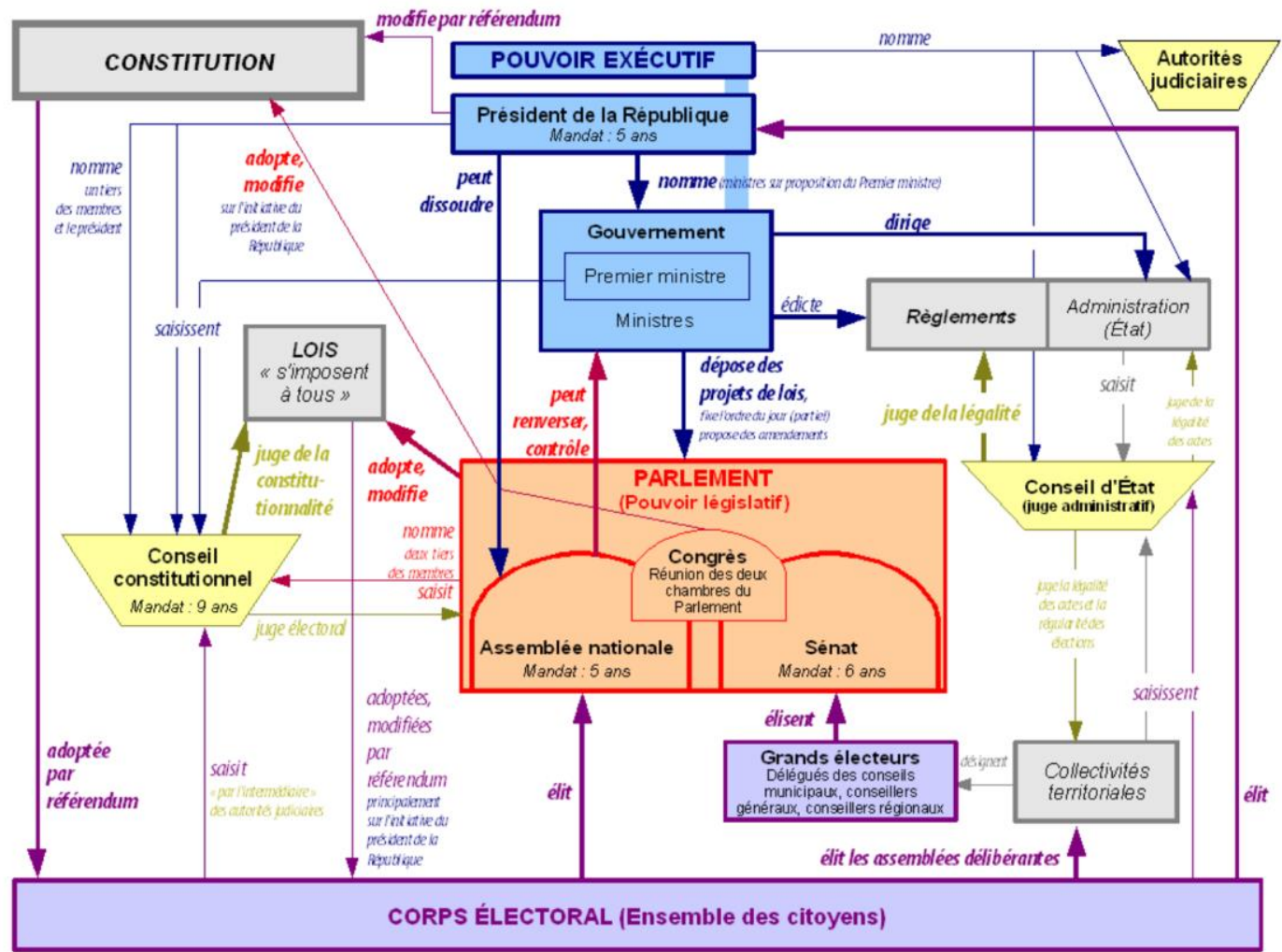

Gambar 4 Institutions of the Fifth Republic

Sumber: Institutions of the Fifth Republic. https://en.wikipedia.org/wiki/French_Fifth_Republic

Berdasarkan gambar 2 diatas, sistem pemerintahan negara Indonesia adalah Presidensil dan berdasarkan gambar 4 sistem pemeritahan negara Prancis adalah semi-presidensil. Parlemen Prancis adalah badan yang terdiri dari Majelis Nasional (Assemblée nationale) dan Senat. Majelis Permusyawaratan Rakyat (MPR) di Indonesia terdiri dari dua kamar yaitu Dewan Perwakilan Rakyat (DPR) dan Dewan Perwakilan Daerah (DPD). 


\section{Jurnal IImu Sosial dan IImu Administrasi Negara Vol.05 No.02 Tahun 2021}

Tabel 2

Perbandingan Indonesia dan Prancis dari Aspek Ekonomi, Kesehatan dan Pendidikan

\begin{tabular}{|c|c|c|c|c|c|}
\hline France & & & & & Indonesia \\
\hline \multicolumn{6}{|c|}{ Gouvernement } \\
\hline Annual GDP [+] & 2019 & $2,715,580 \mathrm{M} . \$$ & $1,022,454 \mathrm{M} . \$$ & 2018 & Annual GDP [+] \\
\hline GDP per capita [+] & 2019 & $40,411 \$ L$ & $3,871 \$$ & 2018 & GDP per capita [+] \\
\hline Debt [+] & 2019 & $2,664,529$ & 307,572 & 2018 & Debt [+] \\
\hline Debt (\%GDP) [+] & 2019 & $98.10 \% \quad L$ & $30.09 \%$ & 2018 & Debt $(\% G D P)[+]$ \\
\hline Debt Per Capita [+] & 2019 & $39,761 \$$ & $1,164 \$$ & 2018 & Debt Per Capita [+] \\
\hline Deficit (M.\$) [+] & 2019 & $-81,512\lfloor$ & $-17,902$ & 2018 & Deficit (M.\$) [+] \\
\hline Deficit (\%GDP) [+] & 2019 & $-3.00 \% \not$ & $-1.75 \%$ & 2018 & Deficit (\%GDP) [+] \\
\hline Expenditure (M.\$) [+] & 2019 & $1,509,667.0 \mathrm{~L}$ & $170,104.0$ & 2018 & Expenditure (M.\$) [+] \\
\hline Education Expenditure (M.\$) [+] & 2015 & $133,296.6$ & $30,845.5$ & 2015 & $\begin{array}{l}\text { Education Expenditure (M.\$) } \\
{[+]}\end{array}$ \\
\hline $\begin{array}{l}\text { Education Expenditure (\%Bud.) } \\
{[+]}\end{array}$ & 2015 & $9.66 \%\lfloor$ & $20.50 \%$ & 2015 & $\begin{array}{l}\text { Education Expenditure } \\
\text { (\%Bud.) }[+]\end{array}$ \\
\hline Gov. Health Exp.(M.\$) [+] & 2018 & $259,094.3 \mathrm{~K}$ & $14,680.1$ & 2017 & Gov. Health Exp.(M.\$) [+] \\
\hline Gov. Health Exp. (\%Bud.) [+] & 2017 & $15.47 \%$ & $8.73 \%$ & 2017 & Gov. Health Exp. (\%Bud.) [+] \\
\hline Defence Expenditure (M.\$) [+] & 2018 & $63,775.1 \mathrm{~L}$ & $7,325.3$ & 2018 & Defence Expenditure (M.\$) [+] \\
\hline $\begin{array}{l}\text { Defence Expenditure (\%Bud.) } \\
{[+]}\end{array}$ & 2018 & $4.10 \%$ & $4.29 \%$ & 2018 & $\begin{array}{l}\text { Defence Expenditure (\%Bud.) } \\
{[+]}\end{array}$ \\
\hline Expenditure (\%GDP) $[+]$ & 2019 & $55.60 \%$ & $16.64 \%$ & 2018 & Expenditure (\%GDP) [+] \\
\hline Expenditure Per Capita [+] & 2019 & $22,528 \$$ & $644 \$$ & 2018 & Expenditure Per Capita [+] \\
\hline Education Expenditure P.C [+] & 2015 & $2,073 \$ L$ & $121 \$$ & 2015 & Education Expenditure P.C [+] \\
\hline Gov. Health Exp. P.C. [+] & 2018 & $3,871 \$ L$ & $56 \$$ & 2017 & Gov. Health Exp. P.C. [+] \\
\hline Defence Expenditure P.C. [+] & 2018 & $985 \$ L$ & $28 \$$ & 2018 & Defence Expenditure P.C. [+] \\
\hline Moody's Rating [+] & $02 / 21 / 2020$ & $\mathrm{Aa} 2$ & Baa2 & $02 / 10 / 2020$ & Moody's Rating [+] \\
\hline S\&P Rating [+] & $11 / 08 / 2013$ & $\mathrm{AA}$ & BBB & 05/31/2019 & S\&P Rating [+] \\
\hline Fitch Rating [+] & $05 / 15 / 2020$ & AA & BBB & $01 / 24 / 2020$ & Fitch Rating [+] \\
\hline Corruption Index [+] & 2018 & $72 \mathrm{~L}$ & 38 & 2018 & Corruption Index [+] \\
\hline Competitiveness Ranking [+] & 2019 & $15^{\circ}\lfloor$ & $50^{\circ}$ & 2019 & Competitiveness Ranking [+] \\
\hline Fragile States Index $[+]$ & 2018 & $32.2 \longleftrightarrow$ & 72.3 & 2018 & Fragile States Index $[+]$ \\
\hline RTI Raking [+] & $09 / 28 / 2018$ & $105^{\circ} \longleftrightarrow$ & $38^{\circ}$ & $09 / 28 / 2018$ & RTI Raking [+] \\
\hline Innovation Ranking [+] & 2018 & $16^{\circ} L$ & $85^{\circ}$ & 2018 & Innovation Ranking [+] \\
\hline
\end{tabular}




\section{MEDIA505IAN}

Jurnal IImu Sosial dan IImu Administrasi Negara Vol.05 No.02 Tahun 2021

Sumber data: Country comparison France vs Indonesia.

https://countryeconomy.com/countries/compare/france/indonesia. Akses 30 Mei 2020.

data diolah.

Berdasarkan data diatas, Jika dibandingkan Gross Domestic Product (GDP) Prancis 2,715,580M.\$ dan 1,022,454M. \$ Indonesia artinya nilai pasar semua barang dan jasa yang diproduksi Pancis $2 \mathrm{x}$ lebih tinggi. Pada aspek renking inovasi Pancis pada posis1 16 (2018) dan Indonesia pada posisi 85 (2018).Berikut dipaparkan data perbandingan pemerintahan Indonesia dan Prancis dari aspek Ekonomi, Kesehatan dan Pendidikan secara lebih lengkap.

\section{REFORMASI MANAJEMEN PUBLIK}

Mengkomparasi reformasi manajemen publik di Indonesia dan Prancis akan menggunakan model reformasi manajemen publik yang diajukan (Savoie, 2012)sebagai berikut.

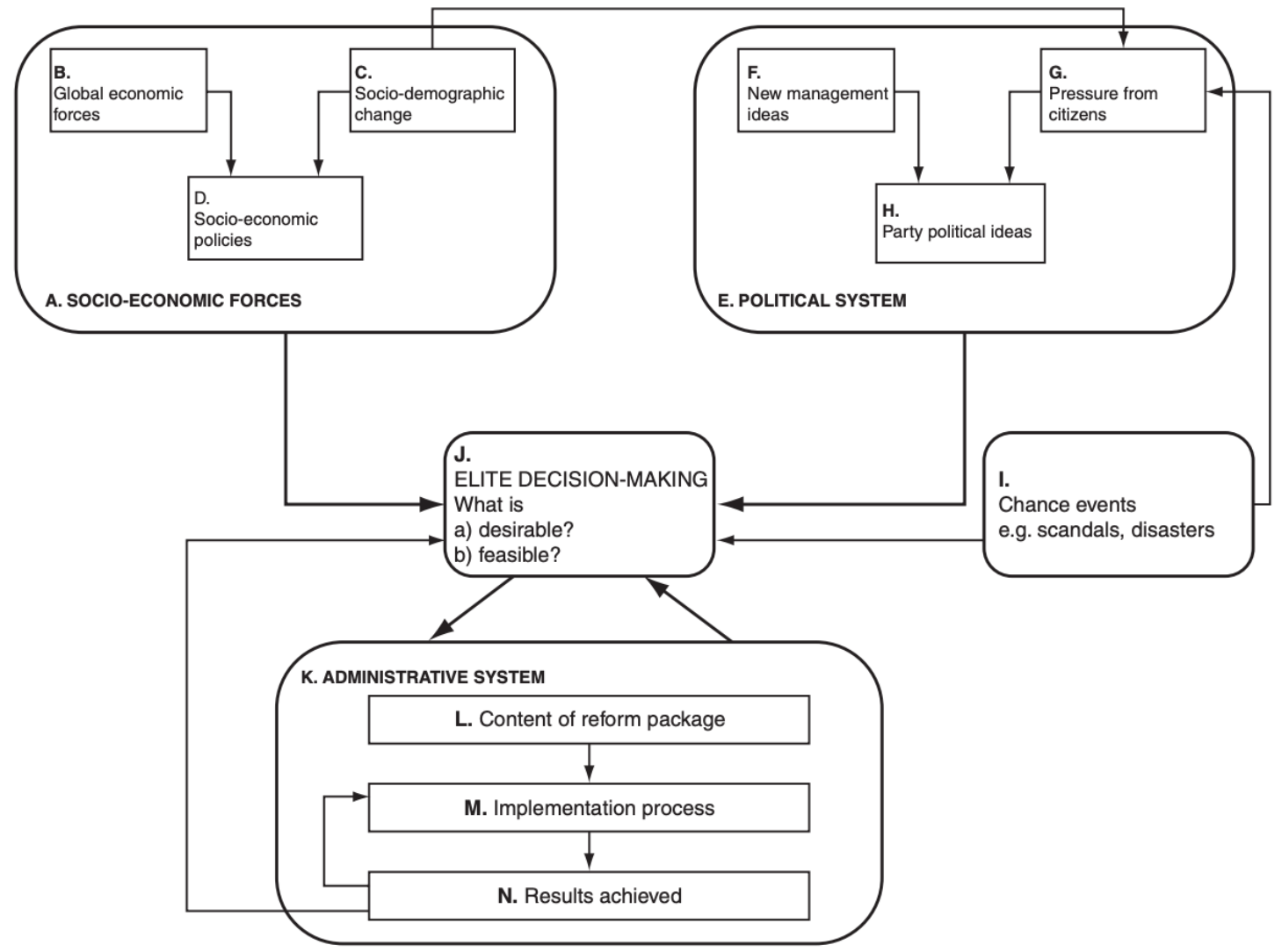

Gambar 5 Reformasi Manajemen Publik. (Savoie, 2012) 


\section{MEDIA505IAN}

Jurnal IImu Sosial dan IImu Administrasi Negara Vol.05 No.02 Tahun 2021

Berdasarkan model diatas, penjelasan (Savoie, 2012) Poin pertama, dan sangat penting adalah bahwa model tersebut menjadikan pemerintah satu negara sebagai kerangka kerjanya. Organisasi dan jaringan internasional sering memainkan peran penting dalam reformasi (Mahon dan McBride, 2009). Namun demikian, keputusan reformasi kunci secara formal diambil oleh pemerintah nasional, bahkan jika mereka melanjutkan di bawah pengaruh jaringan yang lebih luas atau organisasi internasional seperti Organisasi untuk Kerjasama Ekonomi dan Pembangunan, OECD atau Bank Dunia.

Pada bagian tengah-tengah gambar terletak proses pengambilan keputusan elit. Perubahan telah didominasi 'top-down', dalam arti perubahan dipahami dan dilaksanakan oleh politisi eksekutif dan / atau pegawai negeri senior. Reformasi manajemen publik lebih didominasi peran pemerintah pusat yaitu perubahan yang cenderung dimulai di tingkat atas, dan bukan pada jangkauan tata kelola yang lebih rendah, dan yang memungkinkan adanya ukuran pilihan terhadap instrumen dan teknik tertentu yang dipilih. Ada lima kotak utama dalam reformasi manajemen publik: faktor sosial ekonomi (kotak A), faktor sistem politik (kotak E), keputusan elit (kotak J), Sistem Administrasi (kotak K) dan kesempatan (kotak I). pada paper ini akan difokuskan pada reformasi sistem administrasi dilihat dari aspek isi paket kebijakan, proses implementasi dan proses reform.

\section{REFORMASI MANAJEMAN PUBLIK INDONESIA DAN PRANCIS}

\section{Reformasi Manajeman Publik Indonesia}

Indonesia telah mengalami perubahan beberapa sistem pemerintahan yang penting yaitu orde lama, orde baru dan reformasi. Perubahan sistem pemerintahan yang disertai dengan dinamika politik menghasilkan dialektik yang panjang dan perubahan dinamika praktik administrasi publik. Dalam beberapa tahun terakhir, administrasi publik Indonesia telah mengalami reformasi multidimensi termasuk hukum substansial dan struktural. Dapat dikatakan bahwa dinamika internal dan eksternal terlibat dalam proses perubahan. Kekuatan pendorong eksternal untuk reformasi administrasi telah menjadi keinginan Indonesia untuk bekerja sama secara internasional. Ketika Indonesia menjadi bagian dari ASEAN, serta negara-negara lain dan mengalami krisis pada tahun 1997-an, Indonesia melakukan reformasi komprehensif di berbagai 


\section{MEDIA505IAN}

Jurnal IImu Sosial dan IImu Administrasi Negara Vol.05 No.02 Tahun 2021

bidang diantaranya administrasi publik dengan berbagai upaya untuk membangun sistem administrasi yang andal. Krisis ekonomi memaksa meminjam sejumlah dana pada lembaga donor seperti IMF dan Bank Dunia adalah faktor eksternal lain yang mendorong reformasi administrasi publik (Sezen, 2011).

Reformasi Manajeman Publik dilaksanakan untuk mewujudkan prinsip-prinsip good government dalam penyediaan layanan sektor publik. Pada proses reformasi pada dasarnya berkaitan dengan sifat hubungan antara politisi dan pembuat kebijakan, manajer dan penyedia layanan, dan warga negara dan pengguna layanan. Perubahan reformasi manajemen publik paling dinamis di Indonesia terjadi pasca rezim Presiden Soeharto turun dari kekuasaan pada tahun 1998 karena krisis keuangan Asia 1997-1998 dan ketidakpuasan publik karena kenaikan harga-harga kebutuhan pokok yang dipelopori oleh mahasiswa dan organisasi masyarakat sipil, Indonesia memasuki masa transisi reformasi (disebut sebagai era reformasi). Dua administrasi pemerintahan pasca Presiden Suharto yaitu pemerintahan Presiden Habibie dan Presiden Abdurahman Wahid. Aspek yang berubah diantaranya melonggarkan kontrol terhadap pers, memprakarsai program desentralisasi, dan membuat paket otonomi khusus untuk Aceh dan Papua, mulai mereformasi sistem pemilihan presiden, dan perbaikan layanan publik.

Reformasi juga dilakukan melalui langkah-langkah untuk mengurangi peran dwi fungsi TNI dalam politik dan ekonomi. Reformasi berlanjut pada masa pemerintahan Presiden Megawati Sukarnoputri (2001-2004), dan kemudian Presiden Susilo Bambang Yudhoyono, yang menang dalam pemilihan umum pada tahun 2004, dan terpilih kembali pada tahun 2009, dilanjutkan dengan Presiden Joko Widodo yang terpilih pada tahun 2014-2019 dan 2019-2024. Berikut dipaparkan reformsi manajemen publik untuk meningkatkan pelayanan pada rentang waktu 19982009 di Indonesia.

Tabel 3 
Reformsi Manajemen Publik untuk Meningkatkan Pelayanan 1998-2009 di Indonesia

\begin{tabular}{|c|c|c|}
\hline Pathway & $\begin{array}{l}\text { Theorized service delivery } \\
\text { improvement impacts }\end{array}$ & Constraints and risks \\
\hline Decentralization & $\begin{array}{l}\text { - Increases accountability \& } \\
\text { responsiveness (shortens long route } \\
\text { of service accountability) } \\
\text { - Matches services to users' needs \& } \\
\text { preferences } \\
\text { - Increases allocative \& technical } \\
\text { efficiency of service delivery } \\
\text { - Creates positive incentives for } \\
\text { performance }\end{array}$ & $\begin{array}{l}\text { - Partial decentralization creates } \\
\text { perverse incentives } \\
\text { - Unclear delegation of } \\
\text { responsibilities, authorities \& } \\
\text { resources generates conflicts, } \\
\text { ambiguities \& service gaps } \\
\text { - Subnational preferences may } \\
\text { undermine national priorities } \\
\text { - Requires local capacity } \\
\text { - Local elite capture }\end{array}$ \\
\hline Standard-setting & $\begin{array}{ll}\text { - } & \text { Clarifies performance } \\
\text { quantity/quality } \\
\text { - } \\
\text { - } \text { Estanforces professionalism } \\
\text { criteria } \\
\text { - } \begin{array}{l}\text { Provides input to RBM \& PBP } \\
\text { systems }\end{array}\end{array}$ & $\begin{array}{l}\text { Dependent upon accurate } \\
\text { specification of standards } \\
\text { May confront measurement } \\
\text { problems } \\
\text { - Utility connected to effective } \\
\text { communication and dissemination } \\
\text { - Professional bodies may use } \\
\text { standards to exclude new entrants, } \\
\& \text { self-protection }\end{array}$ \\
\hline $\begin{array}{l}\text { Results-based } \\
\text { management } \\
(\mathrm{RBM})\end{array}$ & $\begin{array}{l}\text { Integrates planning, budgeting, } \\
\text { performance monitoring } \\
\text { Creates accountability incentives for } \\
\text { results } \\
\text { - Connects managerial effort to } \\
\text { service outcomes }\end{array}$ & $\begin{array}{l}\text { Technical constraints on specifying } \\
\text { results \& tasks, determining and } \\
\text { costing task components, observing } \\
\text { \& measuring performance } \\
\text { Multi-actor networks muddy } \\
\text { accountability \& encourage blame- } \\
\text { shifting } \\
\text { May create incentives for risk } \\
\text { aversion and pro forma fulfillment } \\
\text { of targets }\end{array}$ \\
\hline $\begin{array}{l}\text { Performance- } \\
\text { based payment } \\
\text { (PBP) }\end{array}$ & $\begin{array}{l}\text { - Creates financial incentives for } \\
\text { service delivery performance } \\
\text { - Clarifies accountability for service } \\
\text { provision } \\
\text { - Increases resource utilization } \\
\text { efficiency \& effectiveness } \\
\text { - Empowers consumers }\end{array}$ & $\begin{array}{l}\text { Dependent upon effective target- } \\
\text { setting, measurement \& verification } \\
\text { - Some aspects of performance are } \\
\text { hard to specify \& measure } \\
\text { - Potentially vulnerable to provider } \\
\text { "gaming" (e.g., adverse selection, } \\
\text { moral hazard) } \\
\text { - Requires management capacity to } \\
\text { operate effectively }\end{array}$ \\
\hline $\begin{array}{l}\text { Information } \\
\text { flows and } \\
\text { transparency }\end{array}$ & $\begin{array}{l}\text { Mitigates knowledge/information } \\
\text { asymmetries among policymakers, } \\
\text { providers \& service users } \\
\text { - } \quad \text { Enables accountability } \\
\end{array}$ & $\begin{array}{l}\text { - May be susceptible to manipulation, } \\
\text { misinterpretation \& misuse } \\
\text { - Political \& bureaucratic barriers can } \\
\text { impede flows, undermine }\end{array}$ \\
\hline
\end{tabular}




\section{MEDIA505IAN}

Jurnal IImu Sosial dan IImu Administrasi Negara Vol.05 No.02 Tahun 2021

\begin{tabular}{|c|c|c|}
\hline Pathway & $\begin{array}{l}\text { Theorized service delivery } \\
\text { improvement impacts }\end{array}$ & Constraints and risks \\
\hline & $\begin{array}{l}\text { Provides empirical base for RBM } \\
\text { and PBP; evidence-based decision- } \\
\text { making } \\
\text { - Enables citizen participation }\end{array}$ & $\begin{array}{l}\text { transparency } \\
\text { - Capacity gaps may limit collection, } \\
\text { analysis, dissemination }\end{array}$ \\
\hline $\begin{array}{l}\text { Citizen } \\
\text { participation: } \\
\checkmark \text { Satisfaction } \\
\checkmark \text { surveys } \\
\checkmark \text { Community } \\
\text { oversight } \\
\checkmark \text { Service co- } \\
\text { production }\end{array}$ & $\begin{array}{ll}\text { - } & \text { Communicates user needs \& } \\
\text { demands to providers \& } \\
\text { policymakers } \\
\text { - } \\
\text { - } \\
\text { - } \text { Increases accountability } \\
\text { - } \\
\text { Promotes preference matching } \\
\text { \& mobilization of multiple sources } \\
\text { of expertise/knowledge }\end{array}$ & $\begin{array}{l}\text { Accuracy of citizen surveys } \\
\text { influenced by past experience, } \\
\text { expectations, \& observability of } \\
\text { performance }\end{array}$ \\
\hline
\end{tabular}

Sumber: (Brinkerhoff \& Wetterberg, 2013)

\section{Reformasi Manajeman Publik Prancis}

Perubahan dalam praktik administrasi sektor publik Perancis telah berjalan hampir tiga perempat dari semua struktur manajemen menggunakan instrumen manajemen SDM baru dan standar peralatan teknologi informasi (TI) yang tinggi dan bahkan lebih baik daripada di sektor swasta (Guillemot, Perrin, 2010). Prevalensi umum dari tujuan dan sejumlah layanan yang dipengaruhi oleh persaingan dari sektor swasta atau yang telah ditenderkan ke sektor swasta sebagaimana disampaikan (Savoie, 2012) tentang reformasi di Perancis sebagai bagian negaranegara Eropa continental. Hal tersebut didasarkan pada praktik-praktik manajemen detail (overhaul) daripada benchmarking praktik-praktik pasar. Layanan tersebut dikualifikasikan oleh tingkat kemitraan swasta publik dan perjanjian konsesi layanan yang cukup tinggi (public private partnerships and service concession agreements). Praktik administrasi di Prancis juga menerapkan kemitraan antar departemen (joined-up government) yang sering dikaitkan dengan model pasca 
Jurnal IImu Sosial dan IImu Administrasi Negara Vol.05 No.02 Tahun 2021

New Public Management (NPM), (Kilby, 2011) terutama di Kementerian pekerjaan umum dan pertanian Pracis. Berikut data reformsi manajemen publik di Prancis.

Tabel 4

Reformsi Manajemen Publik 1980-2006 di Prancis

\begin{tabular}{|c|c|c|c|c|}
\hline & General & Organization & Personnel & Finance \\
\hline $1980-5$ & $\begin{array}{l}1981 \text { Mitterand President } \\
\text { (Socialist) } \\
1981 \text { Mauroy, PM (Socialist) } \\
1984 \text { Fabius PM (Socialist) }\end{array}$ & $\begin{array}{l}1981-2 \text { Nationalization of } 7 \text { industrial groups, } 39 \\
\text { banks, and } 2 \text { financial groups } \\
1982 \text { Decentralization Acts }\end{array}$ & $\begin{array}{l}1981-3 \text { Creation of } \\
82,000 \text { new jobs in the } \\
\text { public sector }\end{array}$ & \\
\hline $1986-90$ & $\begin{array}{l}1986 \text { First elections of regional } \\
\text { councils } \\
1986 \text { Chirac Prime Minister } \\
\text { (Conservative) co-habitation } \\
\text { till } 1988 . \\
1988 \text { Mitterand President (Soc.) } \\
1988 \text { Rocard PM (Socialist) }\end{array}$ & $\begin{array}{l}\text { 1986-7 First privatization wave } \\
1990200 \text { service projects } \\
199060 \text { centres of responsibility } \\
1990 \text { Reform of Post and Telecom starts }\end{array}$ & $\begin{array}{l}\text { 1984-6 Elimination of } \\
12,000 \text { public sector } \\
\text { jobs. } \\
1986-8 \text { Elimination of } \\
33,000 \text { public sector } \\
\text { jobs }\end{array}$ & $\begin{array}{l}1988 \text { Circular on government working methods } \\
\text { introducing cost-effectiveness }\end{array}$ \\
\hline $1991-5$ & $\begin{array}{l}1991 \text { Cresson Prime Minister } \\
\text { (Socialist) } \\
1992 \text { Bérégovoy PM (Socialist) } \\
1992 \text { Act on regional } \\
\text { administration } \\
1993 \text { Balladur Prime Minister } \\
\text { (Conservative) till } 1995 \\
1995 \text { Chirac President } \\
\text { (Conservative) } \\
1995 \text { Juppé PM (Conservative) }\end{array}$ & $\begin{array}{l}\text { 1990-3 Opening of public companies to private } \\
\text { investors } \\
1991 \text { Interministerial Committee on Evaluation } \\
1991 \text { Interministerial Committee for Territorial } \\
\text { Administration (CIATER) } \\
1993 \text { second wave of privatization } \\
1991470 \text { service projects } \\
1991 \text { PTT transformed into two independent public } \\
\text { companies } \\
1992 \text { Deconcentation Charter } \\
1992127 \text { centres of responsibility } \\
1993 \text { Committee for Reorganization and } \\
\text { Deconcentration } \\
1995 \text { Interministerial Committee for State Reform } \\
\text { and State Reform Commission } \\
1993 \text { Report Picq on efficiency of the state }\end{array}$ & $\begin{array}{l}1991 \text { Committee for } \\
\text { Renewal of the Public } \\
\text { Service } \\
1994 \text { Circular on } \\
\text { management of state } \\
\text { employees for } \\
\text { deconcentrated services }\end{array}$ & $\begin{array}{l}1995 \text { Pilot on deconcentration of financial control } \\
\text { of deconcentrated spending }\end{array}$ \\
\hline $1996-2000$ & $\begin{array}{l}1997 \text { Jospin PM (Socialist) } \\
\text { cohabitation till } 2002 \\
\text { 1998 Santel report on } \\
\text { deconcentration }\end{array}$ & $\begin{array}{l}1996 \text { Cour des Comptes report on responsibility } \\
\text { centres } \\
1996 \text { All prefectures become responsibility centres } \\
1997 \text { Balladur launches TQM } \\
1998 \text { State Reform Commissionreplaced by General } \\
\text { Direction of the Administration and Civil Service } \\
1998 \text { Multiannual Programme of Modernization } \\
1998 \text { and 1999: Third privatization waves (by } \\
\text { Jospin) } \\
1999 \text { Interministerial Delegation for State Reform } \\
\text { (DIRE) replaces State Reform Commission and the } \\
\text { Sub-Directorate for modernization of the General } \\
\text { Directorate for Administration and Public Service } \\
\text { (GDAFP) } \\
2000 \text { E-Gov is objective of State Reform }\end{array}$ & $\begin{array}{l}2000 \text { Limited introduction } \\
\text { of the } 35 \text {-hour week in } \\
\text { the public sector }\end{array}$ & $\begin{array}{l}2000 \text { Failed attempt to merge tax assessment and } \\
\text { tax collection }\end{array}$ \\
\hline
\end{tabular}




\section{MEDIA505IAN}

Jurnal IImu Sosial dan IImu Administrasi Negara Vol.05 No.02 Tahun 2021

\begin{tabular}{|c|c|c|c|c|}
\hline & General & Organization & Personnel & Finance \\
\hline $2001-5$ & $\begin{array}{l}2001 \text { Mauroy report on } \\
\text { decentralization } \\
2002 \text { Chirac President } \\
\text { (Conservative) } \\
2002 \text { Raffarin Prime Minister } \\
\text { (Conservative) } \\
2005 \text { de Villepin Prime Minister } \\
\text { (Conservative) } \\
2002 \text { proportion of cabinet } \\
\text { members with ENA degrees } \\
\text { has fallen from 33\% (1960s) } \\
\text { to } 15 \%\end{array}$ & $\begin{array}{l}2001 \text { Establishment of the Institut de la Gestion } \\
\text { Publique et du Développement Economique } \\
\text { (Ministry of Economic Affairs, Finance, and } \\
\text { Industry) } \\
2001 \text { Carcenac report on e-government } \\
2003 \text { Cour des Comptes report on mixed effects of } \\
\text { performance contracts } \\
2003 \text { Health care reform } \\
2005 \text { Creation of a Directorate General for State } \\
\text { Modernization within the Ministry of Finance. } \\
\text { This merged the Directorate for Budgetary } \\
\text { Reform with three offices previously attached to } \\
\text { the Prime Minister- -the Office for Modernization } \\
\text { of Public Management and State Structures, the } \\
\text { Office for Service Users and Administrative } \\
\text { Simplification and the Electronic Administration } \\
\text { Development Agency. This was therefore a } \\
\text { strengthening of the hand of the Ministry of } \\
\text { Finance (Bezes, 2007, p. } 87 \text { ). With } 68 \text { contract } \\
\text { staff out of a total of } 115 \text { A grades it also became } \\
\text { a channel for consultants from the private sector } \\
\text { firms to get involved in state reform (Eymeri- } \\
\text { Douzans, 2009) }\end{array}$ & $\begin{array}{l}2003 \text { Strikes because of } \\
\text { Raffarin's proposals for } \\
\text { public retirement } \\
\text { reforms } \\
2003 \text { ENA candidates } \\
1705 \text { for } 100 \text { positions } \\
\text { (historical high) } \\
2003 \text { Pilit on performance } \\
\text { bonuses for senior } \\
\text { bureaucrats }\end{array}$ & $\begin{array}{l}2001 \text { Loi Organique relative aux Lois de Finances } \\
\text { (LOLF) } \\
2001 \text { Reform of Public Procurement Code }\end{array}$ \\
\hline 2006-10 & $\begin{array}{l}2007 \text { Sarkozy President } \\
\text { (Conservative) } \\
2007 \text { Fillon PM (Conservative) } \\
2010 \text { Decree (16 February) } \\
\text { establishing the authority of } \\
\text { regional prefects over } \\
\text { departmental ones }\end{array}$ & $\begin{array}{l}2007 \text { RGPP General Review of Public Policies } \\
2007 \text { Merger of Directorate General of Taxation, } \\
\text { and Directorate General of Public Accounts } \\
\text { (merging also tax assessment and collection) } \\
2008 \text { Large mergers resulting in mega ministries: } \\
\text { MINEFI (economy, finance, and industry) with } \\
\text { Employment and Civil Servants: Minister of } \\
\text { Budget, Public Accounts, and Civil } \\
\text { Administration. Also, creation of a Ministry of } \\
\text { Immigration, Integration, National Identity, and } \\
\text { Co-Development; } \\
\text { Creation of MEEDDAT (Ministry of Environment, } \\
\text { Energy, Sustainable Development, and Planning) } \\
\text { merging four ministries } \\
2008 \text { Dati Reform reducing number of courts from } \\
1190 \text { to } 866\end{array}$ & $\begin{array}{l}2008 \text { Silicani White Paper } \\
\text { on the future of the } \\
\text { public service }\end{array}$ & $\begin{array}{l}2007 \text { Merger of Directorate General of Taxation } \\
\text { (DGI) with Directorate General of Public Accounts } \\
\text { (DGCP). The accompanying measures to this } \\
\text { large-scale merger of financial administrations } \\
\text { were--for several million euros-contracted out } \\
\text { to three major consultancy firms } \\
2009 \text { Audit Committee to look at budget reductions } \\
\text { (consisting of the spending ministry, Budget and } \\
\text { Public Accounts ministry, Presidential Staff, and } \\
\text { consultants). } \\
2010 \text { New way of financing universities (activities } \\
\text { and performance) }\end{array}$ \\
\hline
\end{tabular}

Sumber data: (Savoie, 2012).

\section{ANALISIS REFORMASI MANAJEMAN PUBLIK INDONESIA DAN PRANCIS}

Reformasi manajemen publik di Prancis dan Indonesia dilaksanakan oleh kebijakan sosialekonomi nasional sebagai respon dari kekuatan ekonomi global karena persoalan kegagalan defisit fiskal (Prancis) dan krisis keuangan (Indonesia). Tuntutan penerapan good government dengan menerapkan prinsip-prinsip transparansi, efektifitas, efisiensi, terbuka dan kompetitif. Pada negara Prancis diawali terjadi pada 1980 an dan Indonesia diawali 1997-1998. Pada periode waktu sebelumnya tettu ada perubahan reformasi, namun gelombang perubahan besar terjadi pada rentang waktu sebagaimana disebutkan diatas. Globalisasi ekonomi membawa tekanan pada sistem perubahan sistem pemerintahan.

Dinamika reformasi di negara Perancis melanjutkan culture proses perubahannya sendiri, khas dan retorika tentang reformasi administrasi dimana berpusat pada tema-tema modernisasi dan desentralisasi. Selama 1980-an terjadi pergeseran ke arah ide-ide neoliberal di kalangan elit di Kementerian Keuangan Prancis dalam bentuk mendukung modernisasi sektor publik melalui metode sektor swasta, daripada privatisasi maksimal atau pengosongan negara (penjualan BUMN 


\section{MEDIA505IAN}

Jurnal IImu Sosial dan IImu Administrasi Negara Vol.05 No.02 Tahun 2021

ke swasta) (Purwantiasning et al., 2014). Prancis sering dianggap sebagai negara yang cukup tahan terhadap gagasan NPM yang muncul dari Inggris, AS, dan Australia sejak awal 1980-an.

Sebagian besar ilmuwan politik menganggap Prancis sebagai sistem tradisional yang berpusat pada negara, di mana intensitas dan variasi aktivitas kelompok penekan cenderung moderat. Sistem ini cenderung mengarah pada korporatisme sektoral daripada pluralisme aktif, yaitu pemerintah telah melakukan kesepakatan dengan sejumlah kecil elit puncak (pengusaha besar, serikat pekerja besar), daripada secara khusus pada kelompok. Kesepakatan semacam itu telah difasilitasi oleh frekuensi perpindahan anggota korps besar-besaran antara pemerintah dan posisi bisnis (pan-touflage). Hal ini sehubungan dengan reformasi manajemen publik, tekanan dari warga pada umumnya tampaknya terbatas. Namun demikian, telah ada penurunan kepercayaan publik pada sistem Perancis. Kritik juga terjadi pada kekakuan beberapa layanan publik, korupsi dari beberapa elit negara.

Indonesia masa pemerintahan orde baru dibawah kepemimpinan Presiden Suharto (19671998), sistem pemerintahan di Indonesia cenderung sentralisme. Pemerintahan dijalankan elit yang ada di Jakarta. Kondisi ini berubah dengan persoalan ekonomi terjadi pada 1997-1998 dengan adanya krisis keuangan yang memicu krisis ekonomi di Indonesia. Persoalan tersebut mendorong komunitas donor internasional mendukung transisi Indonesia menuju demokrasi dan pemerintahan yang baik (reformasi). Program reformasi sektor publik bertujuan untuk mendukung program desentralisasi negara pada pemerintah lokal provinsi dan kabupten/kota, meningkatkan efisiensi dan efektivitas administrasi, dan mengarahkan kembali administrasi publik yang lebih responsif terhadap kebutuhan warga negara. Adapun target reformasi pada sektor-sektor utama, seperti kesehatan dan pendidikan.

Reformasi di Prancis bertitik tolak pada kemunculan berbagai kasus korupsi yang dipandang sebagai peristiwa yang berkontribusi terhadap krisis kepercayaan pada 'elit yang berkuasa (Howard, 1998). Persoalan lain adalah penunjukan dan kemudahan lain kepada teman atau rekan dekat pada persoalan-persoalan pemerintahan (cronyism) telah menjadi endemik pada sistem pemerintahan Prancis. Kondisi yang kurang lebih sama terjadi di Indonesia. Pemerintahan yang sentralisme dan kekuasaan yang luas pada masa pemerintahan Presiden Suharto, membuat 


\section{MEDIA505IAN}

Jurnal IImu Sosial dan IImu Administrasi Negara Vol.05 No.02 Tahun 2021

pemerintahan cenderung korupsi, kolusi dan nepotisme (KKN). Kondisi ekonomi yang tidak stabil mendorong dilakukan reformasi.

Pada pemerintahan Prancis, hilangnya legitimasi pemerintah dimata rakyat menjadi faktor yang mendorong elit untuk meluncurkan inisiatif seperti pembuatan dan penerapan piagam layanan publik (public service charter) untuk meningkatkan layanan publik. Ada keinginan untuk merehabilitasi reputasi aparatur negara, tetapi ada perbedaan mengenai cara terbaik untuk melakukannya. Satu garis ketegangan adalah antara elit politik-administrasi pusat dan otonomi yang berkembang dari layanan lapangan dari kementerian dan otoritas regional dan lokal. Pada negara Prancis masih percaya bahwa reformasi teknokratis yang digulirkan oleh pemerintah pusat pada akhirnya dapat berhasil. Pemogokan tahun 1995 memperjelas apa yang seharusnya menjadi bukti bahwa negara Perancis tidak dapat direformasi dengan dekrit. Solusi teknokratis, betapapun dipahami dengan baik, tidak mungkin ada dalam demokrasi modernis individualis. (Howard, 1998) Ide-ide NPM negara-negara Anglo-Saxon telah secara luas dirancang ulang dan dilabel ulang untuk digunakan di Prancis. Manajemen kekuasaan memperdebatkan ide-ide baru NPM telah banyak berperan dalam jaringan elite Prancis (Bezes, 2007).

Kondisi Indonesia 1997-1998 dikarenakan krisis ekonomi yang menyebabkan naiknya harga-harga kebutuhan pokok mendorong mahasiswa dan masyarakat turun kejalan (berdemontrasi) menuntut turunnya Presiden Suharto dari pusaran kekuasaan. Kondisi ini disebabkan karena legitimasi negara dimata rakyat hilang. Ide-ide reformasi digulirkan pasca turunnya Presiden Suharto dari kepemimpinan nasional diantaranya Desentralisasi, pengaturan standarisasi, Results-based management (RBM)Performance- based payment (PBP), Information flows and transparency dan peningkatan partisipasi warga negara melalui survei kepuasan masyarakat atas layanan publik, Pengawasan komunitas, dan mempromosikan sinergi layanan serta mobilisasi berbagai sumber keahlian / pengetahuan.

\section{REFORMASI SISTEM ADMINISTRASI}

Sistem Perancis adalah model hukum dalam arti bahwa aturan hukum yang menganggap administrasi negara sebagai domain otonom terpisah dari masyarakat sipil (Purwantiasning et al., 2014). Perancis telah memiliki tradisi administrasi yang kuat sejak masa Napoleon. Reformasi 


\section{MEDIA505IAN}

Jurnal IImu Sosial dan IImu Administrasi Negara Vol.05 No.02 Tahun 2021

teknokratis menjadi pilihan. Arah terpusat dari aparatur negara oleh dua set korps besar. Set pertama bersifat administratif dan terdiri dari Inspection des Finances (semacam inspektorat keuangan), Conseil d'Etat (Dewan Negara-pengadilan administrasi tertinggi) dan Cour des Comptes (kantor audit nasional). Grup ini merekrut anggota mereka dari Ecole Nationale d'Administration (ENA). Hingga tahun 1993, delapan dari sebelas perdana menteri adalah pegawai negeri sipil, dan antara tahun 1997 dan 2002, presiden, perdana menteri, dan para menteri keuangan dan pertumbuhan ekonomi, urusan luar negeri, pertahanan dan interior, keadilan, urusan sosial dan pekerjaan, dan pegawai negeri sipil semuanya adalah Enarques (Individu yang dipilih oleh aparatur negara).

Indonesia sebagai negara yang sebelumnya dijajah Belanda mendapat pengaruh kuat pada tatanan pemerintahan. Sistem pemerintahan Indonesia lebih condong ke continental. Salah satu karakteristik utama dari Eropa Kontinental (civil law) ialah penggunaan aturan-aturan yang tertulis dan terbukukan (terkodifikasi) sebagai sumber hukumnya. Reformasi yang digulirkan di Indonesia satu contoh mengubah sistem sentralisasi menjadi desentralisasi dengan disahkannya UU Otonomi daerah. Desentralisasi adalah jalur utama untuk meningkatkan penyampaian layanan, secara luas yang memungkinkan peningkatan kinerja dengan menggerakkan pemerintah lebih dekat dengan orang-orang yang dilayani. Dalam hal accountability triangle agen utama, desentralisasi menciptakan simpul subnasional tambahan dari aktor-aktor negara, dan mengalihkan pemberian layanan kepada entitas lokal (publik, nirlaba, atau swasta) sehingga memperpendek jalan panjang menuju akuntabilitas. Desentralisasi meningkatkan efisiensi alokatif melalui layanan yang sesuai dengan preferensi warga negara, meningkatkan efisiensi produksi layanan dan pengurangan biaya, serta menyelaraskan sumber daya dengan tanggung jawab pemberian layanan melalui berbagai kombinasi transfer antar pemerintah dan pendapatan dari sumber sendiri (Birner \& Von Braun, 2009).

\section{REFORMASI INDONESIA DAN PRANCIS}

Pada negara Prancis dua paket reformsi yang utama adalah, pertama, desentralisasi dan dekonsentrasi dan, kedua, modernisasi. Pergeseran strategis menuju desentralisasi terjadi pada pertengahan 1980-an, ketika pemerintah sosial di bawah Presiden Mitterand mengeluarkan tutor 


\section{MEDIA505IAN}

Jurnal IImu Sosial dan IImu Administrasi Negara Vol.05 No.02 Tahun 2021

para prefek dan menciptakan universitas lokal sebagai otoritas otonom. Pemilihan langsung dilakukan untuk dewan daerah, dan undang-undang selama tahun 1982 memberikan kolektivitas lokal yang signifikan dalam perpajakan dan kekuatan pembuatan anggaran. Desentralisasi berarti pengalihan wewenang dari negara pusat ke pemerintah daerah dan daerah. Dekonsentrasi berarti pelimpahan kompetensi dan wewenang manajerial kepada unit administrasi lokal dari pemerintah pusat. Reformasi pertama, otonomi dalam manajemen personalia, dalam manajemen anggaran, dan untuk keputusan administratif telah ditransfer ke layanan negara-negara dekonsentrasi. Kedua yaitu modernisasi. Perubahan modernisasi menjadi terkenal di bawah Perdana Menteri Rocard pada tahun 1989, meskipun diskusi dan inisiatif sebelumnya telah terjadi sepanjang tahun 1980an. Pada bulan Februari 1989 Rocard mengeluarkan surat edaran penting berjudul Renouveau $d u$ service public yang berisi serangkaian inisiatif penciptaan pertanggungjawaban (Centers de responsabilite CDRs) di dalam kementerian, reformasi kepegawaian, penekanan yang lebih besar pada manajemen terdesentralisasi layanan. Ketiga adalah privatisasi. Pada pemerintah neoliberal Chirac (1986-8) mendaftarkan enam puluh lima perusahaan yang akan dijual ke publik.

Reformasi di Indonesia diarahkan pada Desentralisasi, pengaturan standarisasi, Resultsbased management (RBM), Performance based payment (PBP), Information flows and transparency dan peningkatan partisipasi warga negara. Desentralisasi aspek utama untuk meningkatkan penyampaian layanan secara luas pada masyarakat. Tujuannya untuk memungkinkan peningkatan kinerja dengan menggerakkan pemerintah lebih dekat dengan orangorang yang dilayaninya. Penetapan standar pemberian layanan diterjemahkan ke dalam peraturan dan ditentukan dalam kontrak kinerja. Standarisasi sistem dan prosedur organisasi publik yang secara formal menggabungkan penetapan target, penganggaran yang menghubungkan target dengan pendanaan, pengukuran kinerja dan pemantauan terhadap target, dan akuntabilitas untuk hasil. RBM dan PBM hakikatnya adalah upaya mengintegrasikan prinsip NPM dalam sistem pemerintahan. NPM menyebabkan perhatian pada kontrak sebagai sarana untuk meningkatkan kinerja dan akuntabilitas dan memotivasi agen untuk memenuhi tujuan. Jalur menuju peningkatan kinerja pemberian layanan ini juga telah terbukti semakin populer di negara-negara berkembang, yang telah lama digunakan di sektor infrastruktur. Transparansi dimaksud untuk ketersediaan dan penyebaran informasi mengenai kebijakan, program, alokasi sumber daya, dan hasil relatif 


\section{MEDIA505IAN}

Jurnal IImu Sosial dan IImu Administrasi Negara Vol.05 No.02 Tahun 2021

terhadap layanan adalah elemen inti dari jalur lain menuju peningkatan penyediaan layanan. Partisipasi warga dimaksud untuk penyampaian layanan, menggabungkan pendapat dan agregasi permintaan (survei kepuasan warga negara), pemberdayaan dan tindakan kolektif (pemantauan warga / masyarakat), kekuatan pasar dan produksi bersama layanan.

\section{KESIMPULAN}

Berdasarkan paparan data dan analisis disimpulkan sebagai berikut: reformasi manajemen publik di Indonesia mempertahankan banyak fitur inti dari negara neopatrimonial yang fundamental, di mana elit politik dan ekonomi yang berkuasa melakukan kontrol ketika beroperasi dalam administrasi publik Weberian. Kekuatan politik orde baru yang bertahan lama di Indonesia dari pola-pola lama politik patronase yang didominasi elit dan korupsi yang mengurita. Reformasi manajemen publik pada kenyataan terdapat kekuatan yang mendukung patronase politik dan dominasi elit, pada sisi lain ada juga kekuatan yang terus mendorong untuk perubahan. Konvergensi kekuatan internal dan eksternal, administrasi publik Indonesia mengalami reformasi yang signifikan. Dalam inisiasi manajerial reformasi organisasi internasional global seperti IMF, Bank Dunia memainkan peran kunci sementara Uni Eropa muncul sebagai aktor berpengaruh dalam pengenalan reformasi pemerintah di Indonesia. Perubahan dalam sistem konstitusional, pemerintah, ekonomi, dan politik, dan paradigma yang mendasarinya, memiliki dampak tertentu pada sistem dan proses administrasi negara, terutama dalam hubungan antara pemerintah dan masyarakat. Sebenarnya, reformasi manajerial dan pemerintahan memiliki potensi untuk mengubah peran administrasi publik, serta sifat hubungan antara negara dan masyarakat. Kebijakan ekonomi pasar anti-statis, pro-demokrasi, dan pro-kebebasan sebagai kekuatan pendorong reformasi. Sistem politik multi partai menjadi hambatan lain untuk mewujudkan reformasi administrasi yang bertujuan untuk mendirikan administrasi yang meritokratis dan profesional. Kebijakan reformasi Indonesia hakikatnya bertujuan membatasi kekuasaan yang tertanam oleh oligarki birokrasi dalam sistem administrasi politik. Pemerintah juga telah mereformasi manajerial untuk mengintegrasikan ekonomi Indonesia ke dalam ekonomi dunia dan untuk membuat administrasi publik lebih berorientasi bisnis. Keberhasilan NPM di negara-negara 


\section{MEDIA505IAN}

Jurnal IImu Sosial dan IImu Administrasi Negara Vol.05 No.02 Tahun 2021

maju telah menyebabkan promosi berkelanjutan dari doktrin NPM di negara-negara berkembang seperti Indonesia.

Model reformasi negara Prancis sebagaimana negara-negara eropa kontinental berdasarkan modernisasi (Savoie, 2012) Pada negara Prancis, menganggap administrasi negara sebagai domain otonom terpisah dari masyarakat sipil '(Purwantiasning et al., 2014) dan diatur oleh aturan hukum. Perancis telah memiliki tradisi administrasi yang kuat sejak masa Napoleon. Terdapat dua paket reformsi yang utama yaitu pertama desentralisasi dan dekonsentrasi, kedua modernisasi. Reformasi di Prancis bertitik tolak pada kemunculan berbagai kasus korupsi yang dipandang sebagai peristiwa yang berkontribusi terhadap krisis kepercayaan pada elit pemerintah yang berkuasa. Tingkat penyebaran inovasi dan perubahan sumber daya manusia tampaknya lebih sulit daripada perubahan dalam metode kualitas atau implementasi orientasi pengguna. Namun transformasi ini bervariasi dari satu kementerian ke kementerian lainnya. Karakteristik perbedaan antara kementerian sesuai dengan kebijakan yang mengarah berturut-turut di masing-masing kementerian. Tiga dekade kemudian, model reformasi berorientasi pemberdayaan dan pemberdayaan awal 90-an telah meninggalkan jejak setelah pada pekerjaan umum dan kementerian pertanian di mana mereka terutama dilaksanakan. Model reformasi lain yang didasarkan pada penyebaran luas dan penggunaan instrumen pemantauan kerja telah menyebar di seluruh kementerian keuangan sejak tahun 2000. Perbedaan ini menunjukkan di satu sisi bahwa modernisasi dapat mencakup orientasi yang berbeda dan di sisi lain reformasi manajemen publik Prancis telah berlabuh dalam perubahan jangka panjang. Reformasi manajemen Publik di Prancis menempati peran sentral dalam produktivitas negara. Keinginan meningkatkan layanan publik mendorong reformasi dalam kaitannya dengan penanda utama seperti kesetaraan dan netralitas negara dan tugas penyediaan layanan publik.

Berdasarkan studi komparasi reformasi manajemen publik di Indonesia dan Prancis lesson learned yang dapat penulis sampaikan adalah:

a) Pelaksanaan Reformasi pada suatu negara harus memperhatikan aspek proses sosialekonomi, sistem politik, kebijakan elit berkuasa, dan sistem administrasi. 


\section{MEDIA505IAN}

Jurnal IImu Sosial dan IImu Administrasi Negara Vol.05 No.02 Tahun 2021

b) Reformasi pada negara maju maupun negara berkembang cenderung mengarah pada penciptaan good government dengan mengadopsi prinsip-prinsip NPM pada tata pemerintahan.

c) Dorongan reformasi untuk membangun good government dengan menerapkan NPM melalui paket-paket reformasi harus dibaca ulang disesuaikan dengan karakteristik sosial, budaya, politik dan kondisi masyarakat suatu negara.

\section{REFERENSI}

Bezes, P. (2007). The "steering state" model: The emergence of a new organizational form in the French Public Administration. Sociologie Du Travail, 49, e67-e89.

Birner, R., \& Von Braun, J. (2009). Decentralization and public service provision-a framework for pro-poor institutional design. In Does Decentralization Enhance Service Delivery and Poverty Reduction? Edward Elgar Publishing.

Brinkerhoff, D. W., \& Wetterberg, A. (2013). Performance-based public management reforms: experience and emerging lessons from service delivery improvement in Indonesia. International Review of Administrative Sciences, 79(3), 433-457.

Clark.D. (1998). The Modernization of the French Civil Service: Crisis, Change and Continuity', Public Administration, 76:1, Spring, pp. 97-115.

Country comparison France indonesia. dalam https://countryeconomy.com/countries/compare/france/indonesia. Akses 30 Mei 2020.

France-Indonesia relations. https://en.wikipedia.org/wiki/File:France Indonesia Locator.svg. Akses 2 Juni 2020.

France.https://en.wikipedia.org/wiki/France. Akses 2 Juni 2020.

French Fifth Republic.https://en.wikipedia.org/wiki/French_Fifth_Republic. Akses 2 Juni 2020.

Heady, F. (2001). Public Administration, A Comparative Perspective. CRC Press.

Howard, D. (1998). The French strikes of 1995 and their political aftermath. Government and Opposition, 33(2), 199-220.

Indonesia.https://en.wikipedia.org/wiki/Indonesia\#Government_and_politics. Akses 2 Juni 2020. 


\section{MEDIA505IPN}

Jurnal IImu Sosial dan IImu Administrasi Negara Vol.05 No.02 Tahun 2021

Jreisat, J. E. (2005). Comparative public administration is back in, prudently. Public Administration Review, 65(2), 231-242.

Khademian, A. M. (1998). What do we want public managers to be? Comparing reforms. JSTOR.

Kilby, C. (2011). Informal influence in the Asian development bank. The Review of International Organizations, 6(3-4), 223.

Lynn Jr, L. E. (1998). The new public management: How to transform a theme into a legacy. Public Administration Review, 231-237.

Pollitt, Christopher and Geert Bouckaert (2011). Public Management Reform: A ComparativeAnalysis - New Public Management, Governance, and the Neo-Weberian State. Oxford: Oxford University Press, Third Edition.

Purwantiasning, A., Hadiwinoto, A., \& Hakim, L. (2014). Revitalization of Port Area as an Effort to Preserve the Identity of the City Comparative Studies: Clarke Quay-Boat Quay Singapore Albert Dock Liverpool and SundaKelapa Jakarta. XII International Forum. Le Vie DeiMercanti. Aversa, Capri.(Italy).

Riggs, F. W. (1991). Guest editorial: Public administration: A comparativist framework. Public Administration Review, 51(6), 473-477.

Savoie, D. J. (2012). Christopher Pollitt and Geert Bouckaert (2011) Public Management Reform: A Comparative Analysis-New Public Management, Governance, and the Neo-Weberian State. SAGE Publications Sage UK: London, England.

Sezen, S. (2011). International versus domestic explanations of administrative reforms: The case of Turkey. International Review of Administrative Sciences, 77(2), 322-346. 